\title{
PENGARUH PEMANASAN BERULANG (TYNDALISASI) SAUS SPAGHETTI IKAN TUNA TERHADAP DAYA TERIMA DAN PENDUGAAN UMUR SIMPAN DENGAN METODE AKSELERASI MODEL PERSAMAAN ARRHENIUS
}

\section{(Influence of The Recurrent Heating (Tyndalization) Spaghetti Sauce of Tuna on The Acceptance and Estimation of Shelf Life with Acceleration Method of Arrhenius Equation Model)}

\author{
Mariyati Bilang $^{\left.1^{*}\right)}$, Andi Dirpan ${ }^{1)}$,Nur Sakinah ${ }^{2)}$ \\ 1*) Program Studi Ilmu dan Teknologi Pangan, Fakultas Pertanian, Universitas Hasanuddin, Makassar, Indonesia \\ 2) Mahasiswa Program Studi Ilmu dan Teknologi Pangan, Fakultas Pertanian, Universitas Hasanuddin, Makassar, Indonesia \\ *) email Penulis Korespondensi: mariyati_tekpert@yahoo.com
}

\begin{abstract}
ABSTRAK
Saus Spagethi ikan tuna adalah produk olahan dari tomat (Lycopersicum esculentum) dengan penambahan tuna dan ditambahkan beberapa bumbu. Ini memiliki rasa yang khas dan sebagai pelengkap untuk makan spaghetti. Penelitian ini dibagi menjadi dua tahap, tahap penelitian pendahuluan bertujuan untuk mengetahui perlakuan terbaik saus tuna spaghetti yang diberi perlakuan pemanasan berulang 1 hingga 3 kali pemanasan dimana interval 24 jam untuk setiap kali pemanasan, dengan kriteria adalah organoleptik. Hasil tes (warna, rasa, dan rasa) dan jumlah mikroba. Dari hasil penelitian pendahuluan diperoleh perlakuan saus spaghetti terbaik memiliki perlakuan A2 dengan pemanasan 2 kali. Penelitian utama dalam penelitian ini bertujuan untuk menentukan umur simpan dari sampel terbaik dengan menggunakan metode akselerasi model Arrhenius. Produk ini telah disimpan dalam 3 suhu yang berbeda pada $31^{\circ} \mathrm{C}, 38{ }^{\circ} \mathrm{C}$ dan $45^{\circ} \mathrm{C}$. Analisis dan parameter yang digunakan adalah pengukuran $\mathrm{pH}$, total mikroba, asam titrasi total, warna dan tingkat kecerahan organoleptik yang meliputi aroma dan rasa. Hasil analisis mikroba adalah TPC sebagai parameter utama, umur simpan saus spaghetti tuna adalah 78 hari atau 2,6 bulan sedangkan dari analisis fisik (organoleptik) yang memiliki rasa sebagai parameter kunci, usia saus spageti tuna adalah 267 hari. atau 8,9 bulan.
\end{abstract}

Kata Kunci : Tomato, Tuna, Saus Spaghetti, Arrhenius.

\section{ABSTRACT}

Spaghetti sauce of tuna is a processed product of tomato (Lycopersicum esculentum) with the addition of tuna and added some seasoning. It has a typical taste and as a complement to eat spaghetti. This research was divided into two stages, the preliminary research stage aimed to find out the best treatment of tuna spaghetti sauce which was treated with recurrent heating 1 to 3 times of heating wherein interval 24 hours for each time of heating, with the criteria was organoleptic test results (color, flavor, and flavour) and total microbes. From the preliminary research results obtained the best spaghetti sauce treatment has A2 treatment with 2 times heating. The main research in this study aimed to determine the shelf life of the best sample by using the Arrhenius model acceleration method. The product has stored in 3 different temperatures at $31^{\circ} \mathrm{C}, 38^{\circ} \mathrm{C}$ and $45^{\circ} \mathrm{C}$. Analyzes and parameters used were $\mathrm{pH}$ measurement, total microbes, total titrated acids, color and organoleptic brightness levels that include aroma and taste. The result of microbial analysis was TPC as the key parameter, the shelf life of tuna spaghetti sauce was 78 days or 2.6 months while from physical analysis (organoleptic) that has the flavor as the key parameter, the age of tuna spaghetti sauce was 267 days or 8.9 months.

Keywords : Tomato, Tuna, Spaghetti Sauce, Arrhenius. 


\section{PENDAHULUAN}

Buah tomat merupakan komoditas unggulan hortikultura yang mempunyai nilai ekonomis penting di Indonesia (Hortikultura, 2011). Buah tomat (Lycopersicum esculentum Mill) mengandung banyak zat-zat penting seperti protein, lemak, kholoin, tomatin, mineral, histamin, dan vitamin seperti: provitamin A (karoten), B1, B2, B6, C, dan E (Rugayah, Widjaja, \& Praptiwi, 2004). Selain itu, kandungan likopen yang terdapat pada buah tomat merupakan salah satu antioksidan yang memiliki aktivitas dua kali lebih kuat dibanding alfa tokoferol atau vitamin $\mathrm{E}$ bagi kesehatan manusia (Agarwal \& Rao, 2000). Buah tomat merupakan salah satu komoditi pertanian yang mudah rusak, hal ini dapat disebabkan oleh kerusakan mekanis, fisiologis maupun kerusakan yang disebabkan oleh mikrobiologi (mikroba pembusuk) sehingga dapat mempengaruhi penurunan kandungan gizi serta mempengaruhi umur simpan buah tomat. Hingga saat ini, salah satu upaya yang dilakukan untuk memperpanjang daya simpan buah tomat yaitu dengan mengolahnya menjadi produk turunan tomat, salah satu contoh yaitu saus spaghetti. Dengan seiring berkembangnya teknologi, konsumen lebih jelih dalam memilih makanan yang aman (bebas bahan pengawet). Sehingga perlu diterapkan suatu teknik pengolahan yang dapat meperpanjang daya simpan produk pangan tanpa menambahkan pengawet yaitu dengan memperhatikan mutu dan sanitasi bahan serta alat yang digunakan untuk mengolah produk pangan, yakni dengan metode pemanasan berulang (tyndalisasi). Metode tyndalisasi yang diterapkan pada pengolahan produk pangan ini diharapkan dapat membunuh sel vegetatif sekaligus spora mikroba yang terkandung dalam produk pangan sehingga dapat memperpanjang daya simpan produk.

Informasi masa kaduluarsa atau umur simpan merupakan salah satu informasi yang wajib dicantumkan produsen pada kemasan produk pangan sehingga dapat menjadi jaminan keamanan bagi konsumen yang mengonsumsinya. Untuk mengetahui kelayakan tersebut diperlukan suatu analisis yang lebih mendalam seperti faktor fisikokimia dan mikrobiologis yang dapat diuji secara kuantitatif. Pendugaan umur simpan dapat dilakukan dengan menggunakan metode Accelerated Shelf Life Test (ASLT). Metode ASLT adalah metode penentuan umur simpan produk dengan cara menyimpan produk pada kondisi suhu ekstrim sehingga parameter kritis produk mengalami penurunan mutu akibat pengaruh panas dan penentuan umur simpan dapat ditentukan (Arpab \& Syarief, 2000). Metode ASLT ini menggunakan tiga suhu penyimpanan yang mampu memprediksi umur simpan produk yang diuji. Mengacu pada hal yang dipaparkan di atas, maka diperlukan adanya suatu kajian untuk menentukan umur simpan saus spaghetti ikan tuna pada suhu yang berbeda berdasarkan parameter penurunan mutunya dengan mengacu pada model Arrhenius.

Penelitian ini bertujuan untuk mengetahui tingkat kesukaan panelis terhadap saus spaghetti ikan tuna yang diberi perlakuan pemanasan berulang dan menduga umur simpan saus spaghetti ikan tuna yang menjadi perlakuan terbaik dalam penelitian ini.

\section{METODOLOGI PENELITIAN}

\subsection{Alat}

Alat yang digunakan adalah timbangan analitik, erlenmeyer, bulp, pipet volume, hot plate, laminar air flow, autoklaf, inkubator, microwave, magnetic stirrer, termometer, $\mathrm{pH}$ meter, cawan petri, tabung reaksi, vortex, blender, panci, wadah, saringan, panci, sendok, pisau, kompor, bunsen

\subsection{Bahan}

Bahan yang digunakan adalah buah tomat, ikan tuna, bawang merah, bawang putih, bawang bombay, gula, garam, merica, oregano, minyak goreng, air mineral, aluminium foil, tissue, kapas, indicator PP (fenolftalein), $\mathrm{NaOH}$, aquades, $\mathrm{NaCl}$, PCA (Plate Count Agar).

\subsection{Prosedur Penelitian}

\subsubsection{Pembuatan Saus Spaghetti Ikan Tuna}

Tahapan dari pembuatan saos spaghetti ikan tuna yaitu bawang merah halus 5\%,bawang 
putih halus 5\%, dan bawang bombay kasar 5\% ditumis menggunakan minyakgoreng, kemudian campur ikan tuna yang telah dicincang kasar sebanyak 5\%. Tambahkan pure tomat dan cincang buah tomat $70 \%$ dari berat total dengan perbandingan 90 pure tomat : 10 tomat cincang. Aduk hingga homogen sambil menambahkan bumbu-bumbu penyedap seperti garam $1,5 \%$, merica $0,5 \%$, oregano $0,1 \%$, tepung maizena $0,4 \%$ dan 16 Kulit dan biji Pencucian.

Blanching $80-85^{\circ} \mathrm{C}, 5$ menit Daging tomat Penghalusan Pemasakan $80^{\circ} \mathrm{C}, 30$ menit Pure tomat $10 \%$ Tomat $100 \%$ Pencincangan Saus Tomat $90 \%$ Saus tomat spaghetti Penghalusan biji Ekstrak air tomat 2,5\% ekstrak air tomat $2,5 \%$. Setelah homogen, saos spaghetti dimasak hingga mendidih dengan api kecil selama 20 menit. Setelah pemasakan selesai, saos spaghetti dikemas dalam botol jar yang telah disterilisasi dengan menggunakan metode uap panas, kemudian dilakukan exhausting selama 10 menit dengan suhu $100^{\circ} \mathrm{C}$ dengan keadaan tutup jar tidak rapat.

Selanjutnya saus spaghetti ikan tuna yang telah dikemas dalam botol jar disterilisasi dengan suhu $100^{\circ} \mathrm{C}$ selama 30 menit dengan keadaan tutup jar rapat dan dilakukan sebanyak tiga kali berturut-turut selang waktu 24 jam (tyndalisasi) sesuai perlakuan. Lama pemanasanyang efektif yaitu selama 20 menit, dimana pada waktu tersebut suhu pada titik cool point mencapai suhu yang diinginkan $\left(97-99^{\circ} \mathrm{C}\right)$. Saus spaghetti didinginkan kemudian dilakukan pengukuran $\mathrm{pH}$, total asam, organoleptik (hedonik), dan TPC. Perlakuan terbaik saus spaghetti ikan tuna dari penelitian tahap pertama selanjutnya akan ditentukan umur simpannya dengan metode Accelerated Shelf Life Test (ASLT) yang mengacu pada model Arrhenius.

Penyimpanan saus spaghetti ikan tuna dilakukan pada tiga suhu, yakni suhu ruang, $38^{\circ} \mathrm{C}$, dan $45^{\circ} \mathrm{C}$. Pengamatan selama penyimpanan dilakukan pada awal penyimpanan atau hari ke-0 dan kemudian dengan selang waktu 14 hari berturut-turut selama \pm 60 hari. Pengamatan dilakukan terhadap parameter kritis yakni pengukuran $\mathrm{pH}$, total asam, warna (Cromameter), TPC dan organoleptik (aroma dan rasa) dengan metode uji beda dengan skala 1-5.

Pendugaan umur simpan saus spaghetti ikan tuna dengan menggunakan metode Accelerated Shelf Life Test (ASLT) yang mengacu model persamaan Arrhenius. Perlakuan terbaik dari penelitian pendahuluan akan disimpan pada suhu $31^{\circ} \mathrm{C}, 38^{\circ} \mathrm{C}$ dan $45^{\circ} \mathrm{C}$ selama \pm 60 hari. Tiap 14 hari sekali dilakukan analisis mengenai parameter kritis pada saus tomat yang meliputi: pengukuran $\mathrm{pH}$, total asam, warna (Cromameter), TPC dan organoleptik yang meliputi aroma dan rasa dengan menggunakan metode uji beda dengan skala 1-5.

\subsubsection{Pendugaan Umur Simpan}

Batas mutu minimum adalah nilai mutu dimana produk mulai ditolak oleh konsumen (Hough et al., 2006). Langkah-langkah pendugaan umur simpan dengan metode ASLTsebagai berikut:

a. Data hasil analisa produk terhadap waktu diplotkan dalam bentuk kurva sehingga diperoleh tiga persamaan regresi liniernya untuk tiga kondisi suhu penyimpanan produk dengan menggunakan $\mathrm{Y}=\mathrm{a}+\mathrm{bx}$, dimana $\mathrm{Y}$ $=$ nilai karakteristik produk, $\mathrm{x}=$ lama penyimpanan (hari), $\mathrm{a}=$ nilai karakteristik produk pada awal penyimpanan, $\mathrm{b}=$ laju perubahan nilai karakteristik (nilai $\mathrm{b}$ sama dengan nilai $\mathrm{k}$ ).

b. Dari masing-masing persamaan tersebut diperoleh nilai slope (b) yang merupakan konstanta laju reaksi perubahan karakteristik produk atau laju penurunan mutu (k).

c. Untuk menentukan ordo reaksi yang digunakan dibuat grafik ordo nol yaitu hubungan antara nilai $\mathrm{k}$ dengan lama penyimpanan dan ordo satu yaitu hubungan antara ln k dengan lama penyimpanan. Dari kedua persamaan tersebut dipilih ordo reaksi yang mempunyai nilai R2 (determinasi) terbesar (Goncalves et al., 2011). Penurunan mutu ordo nol adalah merupakan penurunan mutu yang konstan yang dinyatakan sebagai persamaan sebagai berikut. 
At - Ao $=-k t$

dimana:

$\mathrm{A}_{\mathrm{t}}=$ Jumlah A pada waktu $\mathrm{t}$

$\mathrm{A}_{\mathrm{o}}=$ Jumlah awal A

$\mathrm{K}=$ laju perubahan mutu

$\mathrm{t}=$ waktu simpan

Plot hubungan antara penurunan mutu dengan waktu penyimpanan pada reaksi ordo 0 . Sedangkan penurunan mutu ordo satu dinyatakan sebagai persamaan sebagai berikut.

$\ln \mathrm{At}-\ln \mathrm{Ao}=-\mathrm{kt}$

Plot hubungan antara penurunan mutu dengan waktu penyimpanan pada reaksi ordo 1.

d. Untuk pendekatan Arrhenius, nilai $\mathrm{k}$ diplotkan terhadap 1/T (K-1) dan $\ln \mathrm{k}$ didapatkan nilai intersep dan slope dari persamaan regresi linier $\ln \mathrm{k}=\ln \mathrm{k} 0-(\mathrm{E} / \mathrm{R})$ $(1 / \mathrm{T})$, dimana ln $\mathrm{k} 0=$ intersep, $\mathrm{E} / \mathrm{R}=$ slope, $\mathrm{E}=$ energi aktivasidan $\mathrm{R}=$ konstanta gas ideal $=1,986 \mathrm{kal} / \mathrm{mol}^{\circ} \mathrm{K}$. Selanjutnya nilai $\mathrm{ln} \mathrm{k}$ pada masing-masing suhu penyimpanan tersebut diplot dengan $1 / \mathrm{T}$.

e. Dari persamaan pada tahapan sebelumnya diperoleh nilai konstanta $\mathrm{k} 0$ yang merupakan faktor pare eksponensial dan nilai energi aktivasi reaksi perubahan karakteristik sari buah $(\mathrm{Ea}=\mathrm{E})$. Dan kemudian ditentukan model persamaan laju reaksi $(\mathrm{k})$ perubahan karakteristik sari buah dengan $\mathrm{k}=\mathrm{k} 0 . \mathrm{e}^{-\mathrm{Ea} / \mathrm{RT}}$ dengan $\mathrm{T}$ adalah suhu penyimpanan.

f. Dengan persamaan Arrhenius dapat dihitung nilai konstanta Arrhenius (k) pada suhu (T) penyimpanan yang ditentukan.

g. Penentuan parameter kunci dengan melihat parameter yang mempunyai energi aktivasi rendah.

h. Umur simpan produk dapat diduga dengan menghitung selisih nilai mutu awal produk dan nilai mutu produk yang tersisa setelah waktu t dibagi dengan laju penurunan mutu (k) pada suhu penyimpanan yang dinyatakan melalui persaman sebagai berikut:

$$
\begin{aligned}
t & =\frac{A o-A t}{k} & & \text { (reaksi ordo nol) } \\
t & =\frac{\ln A o-\ln A t}{k} & & \text { (reaksi ordo satu) }
\end{aligned}
$$

Keterangan:

$\mathrm{t}=$ prediksi umur simpan (hari)

Ao $=$ nilai mutu awal
At $=$ nilai mutu produk yang tersisa setelah waktu t

$\mathrm{k}=$ konstanta reaksi pada suhu penyimpanan yang diinginkan.

\subsubsection{Desain Penelitian}

Penelitian dilakukan dalam 2 tahap, yaitu pada penelitaian pendahuluan menentukan satu perlakuan terbaik berdasarkan hasil uji tingkat kesukaan panelis (hedonik) dan jumlah total mikroba yang terkandung dalam saus spaghetti ikan tuna yang diberikan perlakuan pemanasan berulang dengan selang waktu 24 jam setiap pemanasan. Penelitian pendahuluan menggunakan desain penelitian Rancangan Acak Lengkap (RAL) dengan satu faktor, yaitu faktor pemanasan

$\mathrm{A}_{0}: \mathrm{kontrol} /$ tanpa pemanasan

$\mathrm{A}_{1}$ : pemanasan $1 \mathrm{x}$

$\mathrm{A}_{2}$ : pemanasan $2 \mathrm{x}$

$\mathrm{A}_{3}$ : pemanasan $3 \mathrm{x}$

Perlakuan terbaik saus spaghetti ikan tuna yang diperoleh pada penelitian pendahuluan akan digunakan pada penelitian utama yaitu pendugaan umur simpan saus spaghetti ikan tuna dengan metode Accelarated Shelf Life Test (ASLT) dengan menggunakan model persamaan Arrhenius. Pada pendugaan umur simpan ini, saus spaghetti ikan tuna dikemas menggunakan kemasan botol kaca/ jar, dimana kondisi penyimpanan divariasikan dengan beberapa suhu penyimpanan. Rancangan perlakuan yang dibuat yaitu faktor suhu penyimpanan (T) yang terdiri dari 3 taraf, yaitu:

T1 : suhu ruang

$\mathrm{T} 2: 38^{0} \mathrm{C}$

$\mathrm{T} 3: 45^{\circ} \mathrm{C}$

\section{HASIL DAN PEMBAHASAN}

\subsection{Organoleptik}

Pengujian organoleptik saus spaghetti ikan tuna pada penelitian pendahuluan disajikan pada tabel 1.

Tabel 1. Pengujian Organoleptik Saus Spaghetti Ikan Tuna dengan Perlakuan Pemanasan Berulang 


\begin{tabular}{cccc}
\hline $\begin{array}{c}\text { Perlakuan } \\
\text { Pemanasan }\end{array}$ & Rasa & Warna & Aroma \\
\hline A0 & 4.1 & 3.8 & 3.9 \\
A1 & 3.8 & 3.8 & 3.6 \\
A2 & 4.1 & 4 & 3.9 \\
A3 & 4.0 & 3.9 & 3.8 \\
\hline
\end{tabular}

Data Primer Hasil Penelitian, 2017.

Hasil sidik ragam menunjukkan bahwa perlakuan pemanasan berulang yang diberikan tidak berpengaruh nyata terhadap parameter rasa, warna, dan aroma. Bahan-bahan yang ditambahkan pada proses pengolahan saus spaghetti ikan tuna seperti buah tomat, ikan tuna dan bumbu-bumbu lainnya akan memberikan kontribusi terhadap rasa, warna dan aroma yang khas pada saus spaghetti ikan tuna. Hal ini sesuai dengan pernyataan Organoleptik Abon Ikan Gabus (Sulthoniyah, Sulistiyati, \& Suprayitno, 2013) bahwasanya komponen lain yang dapat mempengaruhi rasa yaitu senyawa kimia yang ditambahkan, adanya interaksi senyawa dengan komponen rasa yang lain akan menaikkan rangsangan pada pada produk.

\subsection{Total Mikroba}

Hasil Analisa sidik ragam menunjukkan bahwa perlakuan pemanasan berulang berpengaruh nyata $(\mathrm{p}<0,05)$ terhadap penurunan total mikroba pada saus spaghetti ikan tuna.

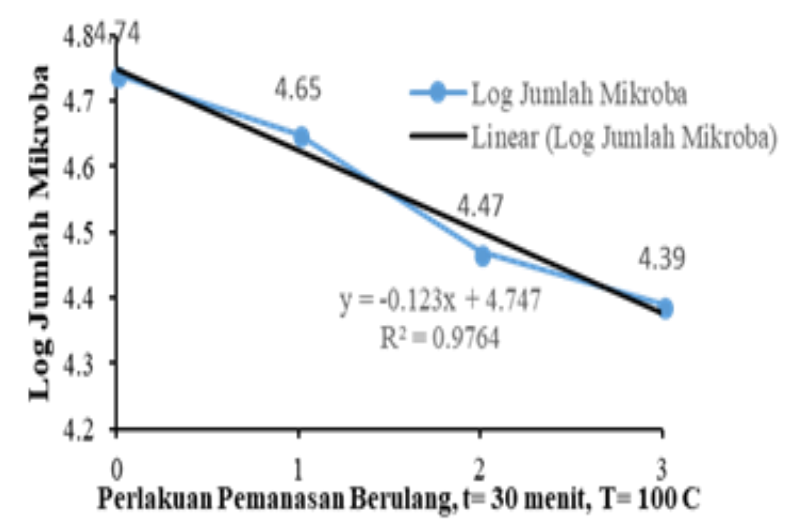

$\begin{array}{ccr}\text { Gambar 1. Pengaruh Pemanasan } & \text { Berulang } \\ & \text { terhadap Penurunan Jumlah } \\ & \text { Mikroorganisme pada } & \text { Saus } \\ & \text { Spaghetti Ikan Tuna }\end{array}$

Jumlah koloni saus spaghtti ikan tuna tanpa perlakuan pemanasan berulang dalam gelas jar yaitu $0,55 \times 10^{5}$. Perlakuan pemanasan pertama menyebabkan penurunan jumlah total mikroba dari $\log 4,74\left(0,55 \times 10^{5}\right)$ menjadi $\log 4,65$ $\left(0,45 \times 10^{5}\right)$. Pada perlakuan pemanasan berulang kedua menyebabkan terjadinya penurunan jumlah mikroba dari $\log 4,65 \quad\left(0,45 \times 10^{5}\right)$ menjadi $\log 4,47\left(0,30 \times 10^{5}\right)$. Dan pada perlakuan pemanasan berulang yang ketiga mikroba yang terkandung dalam saus spagehtti ikan tuna akan semakin lemah oleh tekanan perlakuan pemanasan berulang yang diberikan terhadap saus spaghetti ikan tuna, hingga dengan perlahan jumlah mikroba menurun hingga log 4,39.

Berdasarkan data yang diperoleh, jumlah mikroba pada saus spaghetti ikan tuna yang diberi perlakuan pemanasan berulang tidak dapat terdeteksi. Bedasarkan standar SNI, mikroba dapat dihitung bila terdapat 25-250 koloni dalam suatu pengenceran, sedangkan koloni dalam saus spaghetti ikan tuna hanya terdapat 2-5 koloni pada pengenceran $10^{5}$. Hal ini disebabkan proses pengolahan yang dilakukan secara aseptis dan dengan adanya perlakuan pemanasan berulang yang diberikan dapat mematikan mikroorganisme yang sensitif terhadap panas serta merusak sel-sel vegetatif dan spora secara perlahan sehingga mikroba yang sebelumnya telah terpapar panas akan mengalami kerusakan dinding sel dan setelah 24 jam akan mengalami recorvery kembali kemudian akan mati setelah diberi perlakuan panas berulang (Nursari, Karimuna, \& Tamrin, 2016).

\subsection{Pemilihan Perlakuan Terbaik}

Perlakuan terbaik saus spaghetti ikan tuna pada penelitian pendahuluan dipilih berdasarkan hasil uji organoleptik dengan skor tertinggi dari segi parameter rasa, aroma, dan warna yakni perlakuan A2 dan hasil pengujian total mikroba terkecil dari saus spaghetti ikan tuna. Berdasarkan analisis sidik ragam, perlakuan pemanasan berulang berpengaruh nyata terhadap penurunan jumlah mikroba pada saus spaghetti ikan tuna. Jumlah mikroba pada saus ikan tuna semakin menurun dengan perlakuan pemanasan berulang yang diberikan, dimana perlakuana A3 dengan perlakuan $3 x$ pemanasan mengandung total mikroba lebih rendah dibanding perlakuan $\mathrm{A} 0, \mathrm{~A} 1$ dan $\mathrm{A} 2$. 
Namun dengan melihat efisiensi energi yang digunakan saat pengolahan saus spaghetti ikan tuna dan daya terima panelis (uji organoleptik) terhadap saus spaghetti ikan tuna, maka dipilihlah perlakuan A2 (2x pemanasan) sebagai perlakuan terbaik.

\subsection{Pengukuran Perubahan Mutu Saus Spaghetti Ikan Tuna Selama Penyimpanan}

Penelitian utama ini dilakukan untuk mengamati perubahan mutu saus spaghetti ikan tuna yang dikemas dalam kemasan jar dari segi organoleptik, kimia, fisik dan mikrobiologi selama kurang lebih 8 minggu dengan suhu penyimpanan $31^{\circ} \mathrm{C}, 38^{\circ} \mathrm{C}$ dan $45^{\circ} \mathrm{C}$. Penyimpanan dengan kondisi suhu yang berbeda ini bertujuan untuk mempercepat proses kerusakan saus spaghetti ikan tuna sehingga dapat diperkirakan kondisi kritis dari interaksi beberapa perlakuan suhu yang diberikan.

\subsection{Rasa}

Uji organoleptik parameter rasa saus spaghetti ikan tuna menggunakan uji beda dari kontrol dengan evaluasi sensori selama 8 minggu dengan pengujian sampel setiap 14 hari sekali. Perubahan rasa saus spaghetti ikan tuna selama masa penyimpanan dapat dilihat Gambar 2 .

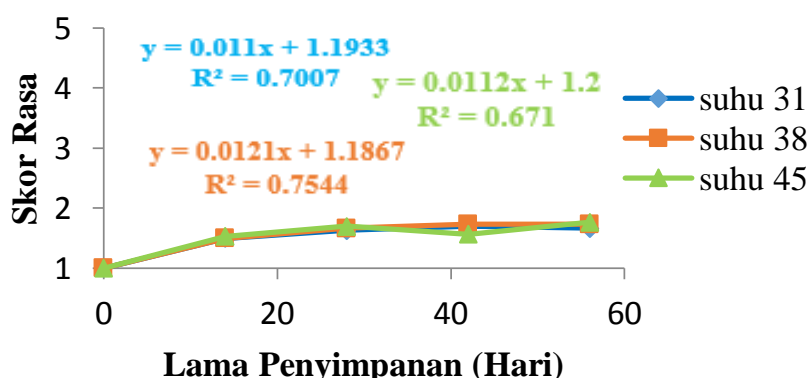

Gambar 2. Perubahan Rasa Saus Spaghetti Ikan Tuna Selama Penyimpanan

Gambar 2. Menunjukkan perubahan aroma untuk variasi suhu $31^{\circ} \mathrm{C}, 38^{\circ} \mathrm{C}$ dan $45^{\circ} \mathrm{C}$ tidak terlalu jauh berbeda hingga penyimpanan hari ke- 56. Berdasarkan pendapat beberapa panelis, pengujian organoleptik parameter rasa menunjukkan adanya perbedaan rasa pada sampel uji dan sampel kontrol pada pengujian hari ke- 42. Perbedaan rasa yang dikemukakan bukanlah perubahan rasa yang menyimpang, melainkan perubahan rasa sampel uji yang lebih enak dibandingkan dengan sampel kontrol, hal ini disebabkan selama masa penyimpanan senyawa-senyawa yang terkandung di dalam saus spaghetti saling berinteraksi satu sama lain sehingga menghasilkan rasa yang kompak. Selain itu, bahan-bahan yang ditambahkan selama proses pengolahan, seperti buah tomat dan ikan tuna memberikan cita rasa yang umami pada saus spaghetti ikan tuna, hal ini disebabkan adanya kandungan asam glutamat yang merupakan salah satu asam amino yang berperan dalam memberikan rasa umami pada produk olahan. Hal ini sesuai dengan pernyataaaan (Subagio, 2006), rasa gurih didapatkan dari senyawa asam-asam amino, seperti: asam glutamat. (Amalia, 2010), menambahkan asam glutamat merupakan sumber rasa umami (gurih) paling dominan dan berdampak pada kesempurnaan atau keaslian dari rasa itu sendiri.

\subsection{Analisis pH}

Pengukuran $\mathrm{pH}$ atau derajat keasaman saus spaghetti ikan tuna bertujuan untuk mengetahui tingkat keasaman produk selama masa penyimpanan. Perubahan $\mathrm{pH}$ saus spaghetti ikan tuna selama masa penyimpanan dapat dilihat Gambar 3.

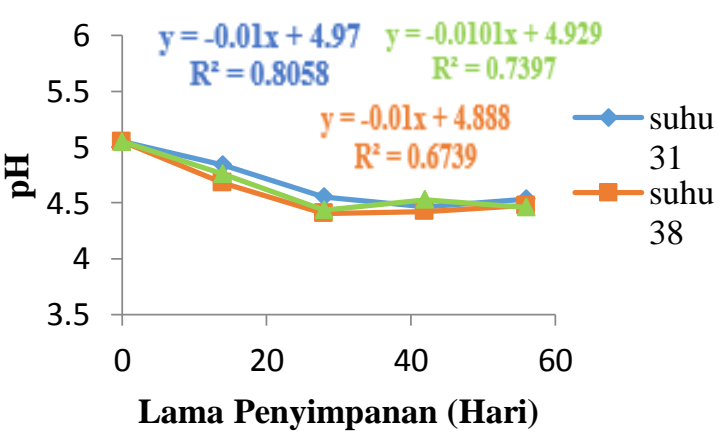

Gambar 3. Perubahan pH Saus Spaghetti Ikan Tuna Selama Penyimpanan.

Gambar 3 menunjukkan bahwa secara keseluruhan hasil pengukuran $\mathrm{pH}$ saus spaghetti ikan tuna selama masa penyimpanan menunjukkan perubahan nilai $\mathrm{pH}$ yang fluktuatif dengan kisaran nilai $\mathrm{pH}$ 4-5. Hal ini dikarenakan pada proses pengolahan tidak ada penambahan senyawa asam yang dapat mempertahankan nilai $\mathrm{pH}$ saus spaghetti ikan tuna, sehingga selama masa penyimpanan nilai 
$\mathrm{pH}$ saus spaghetti ikan tuna fluktuatif. Penambahan asam pada produk olahan dapat menurunkan $\mathrm{pH}$ yang disertai dengan naiknya kosentrasi ion hidrogen $\left(\mathrm{H}^{+}\right)$dan dijumpai bahwa $\mathrm{pH}$ rendah lebih besar dalam menghambat pertumbuhan mikroorganisme (Tranggono \& Sutardi, 1989). Nilai pH saus spaggetti ikan tuna yang rendah berasal dari bahan baku utama yang digunakan yaitu buah tomat yang mengandung asam-asam organik salah satunya yaitu asam sitrat yang berperan dalam menentukan nilai $\mathrm{pH}$ produk

\subsection{Total Mikroba}

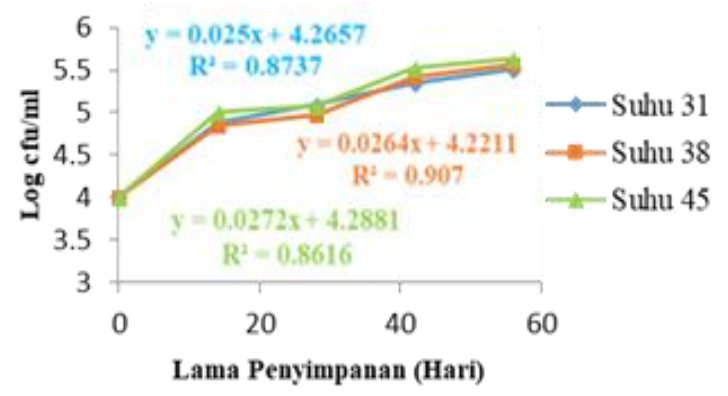

Gambar 4. Perubahan Total Mikroba Saus
Spaghetti Ikan Tuna Selama
Penyimpanan

Berdarkan gambar di atas, peningkatan suhu selama masa penyimpanan dapat menyebabkan meningkatnya populasi mikroba (log $\mathrm{cfu} / \mathrm{ml}$ ) pada saus spaghetti ikan tuna. Hasil pengujian TPC menunjukkan bahwa jumlah mikroba yang terkandung dalam saus spaghetti ikan tuna selama masa penyimpanan masih aman untuk dikonsumsi yakni $4-5,64 \log \mathrm{cfu} / \mathrm{ml}$, baik pada penyimpanan suhu $31^{\circ} \mathrm{C}, 38^{\circ} \mathrm{C}$ dan $45^{\circ} \mathrm{C}$. Total mikroba yang terdapat dalam saus spaghetti ikan tuna masih memenuhi persyaratan SNI bumbu instan pasta, sehingga masih aman untuk dikonsumsi. Standar jumlah mikroba yang ditetapkan oleh SNI 01-3709-1995 yaitu untuk jenis bumbu instan pasta adalah $1 \times 10^{6} \mathrm{koloni} / \mathrm{ml}$ atau 6,0 log cfu/ml. Kenaikan jumlah mikroba pada saus spaghetti ikan tuna disebabkan kandungan nutrisi yang kompleks di dalam saus spaghetti ikan tuna, sehingga dapat digunakan mikroba untuk pertumbuhannya. Selain itu, pada proses pengolahan tidak ada penambahan bahan pengawet berupa asam benzoate atau natrium benzoate sehingga pertumbuhan mikroba pada saus spaghetti ikan tuna selama masa penyimpanan tidak dapat dihambat (Tranggono \& Sutardi, 1989).

\subsection{Penentuan Titik Kritis}

Pendugaan umur simpan saus spaghetti ikan tuna dapat didekati dengan tiga faktor, yakni kandungan mikroba, $\mathrm{pH}$, dan sensori (rasa). Penetapan parameter kritis yang digunakan dalam pendugaan umur simpan adalah spesifik untuk masing-masing produk. Pada produk saus spaghetti ikan tuna parameter mutu kritis kandungan mikroba dan sensori (rasa) digunakan sebagai pendekatan dalam pendugaan umur simpan. Kandungan mikroba pada produk pangan merupakan faktor yang dianggap penting dalam menetapkan keamanan produk selama penyimpanan.

\subsection{Penetapan Ordo Reaksi}

Kecepatan perubahan mutu setiap parameter saus spaghetti ikan tuna berbeda-beda. Jika laju kerusakan terjadi secara konstan atau linier maka mengikuti ordo reaksi nol. Namun jika laju kerusakan terjadi secara tidak konstan, secara logaritmik atau eksponensial, maka mengikuti ordo reaksi satu. Penetapan ordo reaksi merupakan cara untuk memprediksi penurunan mutu dalam pendugaan umur simpan. Dalam reaksi-reaksi kinetika, penurunan mutu bahan pangan mengikuti ordo nol dan ordo satu. Ordo nol dapat dideteksi dengan membuat plot antara nilai kandungan mikroba/ parameter rasa sebagai sumbu $\mathrm{Y}$ dan lama penyimpanan sebagai sumbu X. Sedangkan untuk ordo satu dapat dideteksi dengan membuat plot antara nilai ln nilai kandungan mikroba/ parameter rasa sebagai sumbu $\mathrm{Y}$ dan lama penyimpanan sebagai sumbu X. Pemilihan ordo reaksi dapat dilihat dengan cara memplotkan data penurunan mutu mengikuti ordo nol dan ordo satu, lalu dibuat persamaan regresi liniernya. Ordo reaksi dengan nilai R2 yang lebih besar merupakan ordo reaksi yang digunakan. 
Tabel 2. Nilai slope, intersep dan determinasi saus spaghetti ikan tuna pada reaksi ordo 0 dan ordo 1

\begin{tabular}{|c|c|c|c|c|c|c|c|}
\hline \multirow{2}{*}{$\begin{array}{l}\text { Parameter } \\
\text { Uji }\end{array}$} & \multirow{2}{*}{$\begin{array}{c}\text { Suhu } \\
\text { penyimpanan } \\
\left({ }^{\circ} \mathrm{C}\right)\end{array}$} & \multicolumn{3}{|c|}{ Ordo 0} & \multicolumn{3}{|c|}{ Ordo 1} \\
\hline & & $\begin{array}{c}\text { Kemiringan } \\
(\text { slope })(\mathrm{k})\end{array}$ & Intersept & $\begin{array}{c}\text { Determinasi } \\
(\mathrm{R} 2)\end{array}$ & $\begin{array}{c}\text { Kemiringan } \\
(\text { slope })(\mathrm{k})\end{array}$ & Intersept & $\begin{array}{l}\text { Determinasi } \\
\text { (R2) }\end{array}$ \\
\hline \multirow{3}{*}{ Rasa } & 31 & 0.01 & 1.193 & 0.701 & 0.01 & 0.158 & 0.668 \\
\hline & 38 & 0.01 & 1.187 & 0.754 & 0.01 & 0.154 & 0.713 \\
\hline & 45 & 0.01 & 1.200 & 0.671 & 0.01 & 0.163 & 0.644 \\
\hline \multirow{3}{*}{ TPC } & 31 & 0.025 & 4.266 & 0.874 & 0.005 & 1.450 & 0.843 \\
\hline & 38 & 0.026 & 4.221 & 0.907 & 0.006 & 1.441 & 0.880 \\
\hline & 45 & 0.027 & 4.288 & 0.862 & 0.006 & 1.455 & 0.831 \\
\hline
\end{tabular}

\subsection{Pendugaan Umur Simpan}

Apabila nilai gradien di ln (natural log)-kan dan diplotkan dengan $1 / \mathrm{T}$ (satuan derajat Kelvin) atau satu per suhu mutlak maka diperoleh persamaan Arrhenius seperti yang ditunjukkan pada Tabel 3. Dengan perhitungan kemiringan persamaan regresi antara nilai ln total mikroba/ rasa dan waktu pengujian pada tiga tingkat suhu, didapat nilai $\mathrm{k}$ atau konstanta penurunan mutu produk seperti pada Tabel 3. Secara garis besar nilai konstanta kecepatan reaksi penurunan mutu (K) pada masing-masing suhu penyimpanan dapat diduga dengan persamaan Arrhenius yang diperoleh. Dengan demikian, total unit mutu sampai kadaluwarsa dapat dihitung dengan mengurangkan nilai mutu awal parameter uji (TPC dan rasa) dengan nilai batas kritis parameter uji (TPC dan rasa). Perkiraan umur simpan (ts) saus spaghetti ikan tuna dapat dihitung dengan persamaan ts $=[\ln ($ No-Nt $)] / K T$. Persamaan Arrhenius saus spaghetti ikan tuna Ln $\mathrm{K}=\mathrm{Ln} \mathrm{Ko}-\mathrm{Ea} / \mathrm{R}$ (1/T) dapat dilihat pada Tabel 3. Hasil pendugaan umur simpan saus spaghetti ikan tuna dengan beberapa suhu penyimpanan dapat dilihat pada Tabel 3.

Tabel 3. Persamaan Arrhenius penurunan mutu saus spaghetti ikan tuna pada berbagai suhu penyimpanan

\begin{tabular}{|c|c|c|c|c|c|c|c|}
\hline $\begin{array}{l}\text { Parameter } \\
\text { Uii }\end{array}$ & $\mathrm{T}$ & $\mathrm{K}$ & $\ln \mathrm{k}$ & $\mathrm{T}$ & \multicolumn{2}{|c|}{ Persamaan Linier } & Persamaan Arrhenius \\
\hline & $\left({ }^{\circ} \mathrm{C}\right)$ & & & & $\left({ }^{\circ} \mathrm{K}\right)$ & Ln K vs $1 / \mathrm{T}(\mathrm{oK})$ & $\operatorname{Ln} \mathrm{K}=\mathrm{Ln} \mathrm{Ko-Ea/R}(1 / \mathrm{T})$ \\
\hline \multirow{3}{*}{ Rasa } & 31 & 0.01 & & $\begin{array}{c}- \\
4.514\end{array}$ & 304 & & \\
\hline & 38 & 0.01 & & 4.411 & 311 & $\begin{array}{l}Y=-158,05 x- \\
3,9643 R 2= \\
0,0442\end{array}$ & $\begin{array}{c}\text { Ln } K=-3,964- \\
158,05(1 / T)\end{array}$ \\
\hline & 45 & 0.01 & & $\begin{array}{c}- \\
4.493\end{array}$ & 318 & & \\
\hline \multirow{3}{*}{ TPC } & 31 & 0.005 & & $\begin{array}{c}- \\
5.249\end{array}$ & 304 & \multirow{3}{*}{$\begin{array}{l}Y=-467,27 x- \\
3,7081 R 2= \\
0,9558\end{array}$} & \multirow{3}{*}{$\begin{array}{c}\text { Ln } K=-3,7081- \\
467,27(1 / \mathrm{T})\end{array}$} \\
\hline & 38 & 0.006 & & $\begin{array}{c}- \\
5.202\end{array}$ & 311 & & \\
\hline & 45 & 0.006 & & $5 . \overline{182}$ & 318 & & \\
\hline
\end{tabular}




\section{KESIMPULAN}

Perlakuan terbaik saus spaghetti ikan tuna pada penelitian pendahuluan yakni perlakuan A2 (2x pemanasan) dengan skor rasa 4.1 (Suka), aroma 4 (suka) dan warna 3.9 (suka), pH 3,99, total asam 0,663 dan total mikroba $\log 4,47$. Pendugaan umur simpan saus spaghetti ikan tuna (perlakuan A2) menggunakan metode ASLT dengan pendekatan parameter TPC dan analisa sensori rasa sebagai parameter kritis berturut-turut memiliki umur simpan 77 hari dan 266 hari

\section{DAFTAR PUSTAKA}

Agarwal, S., \& Rao, A. V. (2000). Tomato lycopene and its role in human health and chronic diseases. CMAJ. https://doi.org/10.1016/j.amjsurg.2013.0 9.032

Amalia, F. (2010). Umami sebagai Rasa Dasar ke-5.

Arpab, M., \& Syarief, D. R. (2000). Evaluasi model-model pendugaan umur simpan pangan dari difusi hukum fick unidireksional evaluation of shelf. life equation models derived . From unldffiectional fick's law. Hasil Penelitian Bul. Teknol. Dan Industri Pangan Th, 5(3), 45-48.

Hortikultura, D. J. (2011). Renstra Direktorat Jenderal Hortikultura Edisi Revisi tahun 2010 - 2014.

Nursari, Karimuna, L., \& Tamrin. (2016). pengaruh ph dan suhu pasteurisasi terhadap karakteristik kimia, organoleptik dan daya simpan sambal. Sains Dan Teknologi Pangan, 1(2), 151158.

Rugayah, Widjaja, \& Praptiwi. (2004). Pedoman Pengumpulan Data Keanekaragaman Flora. Bogor: LIPI.

Subagio. (2006). Mengembangkan Terasi Instan. Food Review Indonesia, 1(4), 3436.

Sulthoniyah, S. T. M., Sulistiyati, T. D., \& Suprayitno, E. (2013). Pengaruh Suhu Pengukusan Terhadap Kandungan Gizi dan Organoleptik Abon Ikan Gabus
(Ophiocephalus striatus). THPi Student Journal, $\quad 1(1), \quad 33-45$. https://doi.org/10.1360/112012-402

Tranggono, \& Sutardi. (1989). Biokimia dan Teknologi Pasca Panen. Pusat Antar Universitas Pangan Dan Gizi,. Gadjah Mada University Press. Yogyakarta.

Tranggono, Sutarji, Haryadi, dan A. Murdiati, 1989. Bahan Tambahan Pangan. Proyek Pengembangan Pusat Fasilitas Bersama Antar Universitas Pangan dan Gizi. UGM, Yogyakarta. 